\title{
FITTING LACTATION CURVE OF EGYPTIAN BUFFALO USING THREE DIFFERENT MODELS
}

\author{
S.A.M. Abdel-Salam ${ }^{1}$, W. Mekkawy ${ }^{2}$, Y.M. Hafez ${ }^{1}$, A.A. Zaki ${ }^{1}$, S. Abou- \\ Bakr ${ }^{1}$
}

1- Department of Animal Production, Faculty of Agriculture, University of Cairo, Giza, Egypt, 2- Department of Animal Production, Faculty of Agriculture, University of Ain Shams, Cairo, Egypt

\section{SUMMARY}

The initial dataset included a total of 7819 monthly test-day records of 1205 buffaloes located in six different farms and recorded by Cattle Information System/Egypt (CISE). The buffalo having less than five test-day records were removed from the dataset. The test-day records after 300 days of lactation were excluded from the analysis. Also, the extreme phenotypic values of daily milk yield, fat and protein percentage were removed from the dataset. Three different models were tested for fitting the lactation curve of the Egyptian buffalo, Wilmink (WM), Guo and Swalve (GSM) and Wood (WD).

The expected daily milk yield at the beginning of lactation was 8.90, 9.16 and $9.08 \mathrm{~kg}$ in WM, GSM and WD, respectively, and then increased to reach the peak 10.56, 10.67 and $9.08 \mathrm{~kg}$ in WM, GSM and WD, respectively. Days to attain the peak were 29, 26 and 28 day, in the three models, respectively. The daily milk production was decreased to $2.41 \mathrm{~kg}$ in WM and WD and $2.64 \mathrm{~kg}$ in GSM at the end of the lactation period. The curves of milk fat, protein and lactose yield had similar pattern to the curves of the daily milk yield. The milk fat and protein percentage seem to have an increasing trend with the increasing of days in milk. The curve of milk lactose percentage was in contrast with the curve of the milk fat and protein percentage. The three criteria used to compare the goodness of fit of these models were Mean Square Prediction Error (MSPE) value, Akaike Information Criterion (AIC) and Schwartz's Bayesian Information Criteria (BIC). The goodness-of-fit statistics of the expected curves for daily milk yield and its contents, for the better-fitting models, appear that WD model gave the best fit for the studied criteria.

Keywords: Lactation curve, milk yield, milk constituents

\section{INTRODUCTION}

Empirical algebraic modeling of lactation curves offers a summary of longitudinal milk yield patterns from which cumulative lactation curves can be estimated or by which total milk yield may be predicted from incomplete data. Appropriate models provide useful information for breeding and management decisions at both industry and farm level, and also for the comparison of alternative production strategies in bio-economic modeling. To ensure accurate decisions pertinent to individual animals

Issued by The Egyptian Society of Animal Production 
or herds it is essential that cumulative milk yield is predicted with minimum error and from relatively few test dates, reducing the cost and inconvenience of milk recording. From the bio-economist's viewpoint, the model of lactation curve must accurately depict what is expected at farm level so that a cost can be associated with each cow (Quinn et al., 2005).

Milk production increases from calving to peak then followed by a gradual decline after the end of persistency till the animal goes dry. The graphical representation of milk production throughout the lactation period is the lactation curve which doesn't include the colostrums and transitional milk periods. The description of the lactation curve assists the breeder to predict total milk yield from part lactations and to take early decisions for culling or selection as well as introducing new genetic materials (Sadek et al., 1998, Chaudhry et al., 2000 and Barbosa et al., 2007).

The lactation curve refers to a graphic relation between milk production and lactation time after calving apart the week of colostrum and transitional milk (Papajcsik and Bodero, 1988). Equations that describe milk production in time can be very useful in breeding programs, herd nutritional management, decision taking on the culling cows and simulation of production system. The lactation curve is also important because its wide characterization of the animal production throughout lactation allows estimating the peak yield; lactation persistency and days in milk (Cunha et al., 2010). Kirkpatrick et al. (1990) showed that the phenotypic changes with age could be represented as a function of lactation time.

Empirical mathematical models of lactation curves are regular functions $y=f(t)$, defined for positive values of daily milk production $(y)$ and time from parturition $(t)$, used in the dairy cattle industry for breeding and management purposes. These models represent an essential research tool for developing and validating mechanistic models, aimed at explaining the main features of the milk production pattern in terms of the known biology of the mammary gland during pregnancy and lactation, whereas the biosynthetic capacity of the mammary gland started as early as 45 days prepartum to form the pre-colostrum and accumulates it, then at parturition modifies it to colostrum, followed by transitional milk and finally milk postpartum (Neal and Thornley, 1983 and Mepham, 1987).

When fitted to milk test-day (TD) data, an empirical model must be able to disentangle the continuous component from temporary environmental perturbations and to make predictions on milk yields. Several mathematical functions have been proposed, differing mainly in the type of regression (linear or nonlinear), in the number of parameters and in their degree of relationships with the main features of a typical lactation pattern, such as peak yield, time at peak, and persistency (Macciotta et al., 2005).

Lactation curves in dairy animals have been used extensively for early prediction of total milk yield and thus culling of low producers and forward planning of feed and farm resources. Daily milk yield in dairy buffaloes increases rapidly from calving to a peak in a few weeks, followed by a gradual decline until milk removal is no longer practical. The graph of daily milk production during lactation can be described by the coefficients of a mathematical equation model. An abrupt decline in milk yield after the peak increases production costs because yield is distributed less equally over 
the complete lactation. Dairy buffaloes with a flat lactation curve are considered to have more persistent lactations than those with the same lactation yield but a rapidly declining lactation curve (Anwar et al., 2009).

Information on the shape of lactation curves in dairy buffaloes is very limited. The objective of this study was to fit lactation curve of Egyptian buffalo for milk yield and its contents using three different models of Wood (1967), Wilmink (1987) and Guo and Swalve (1995).

\section{MATERIALS AND METHODS}

\section{Data:}

The initial dataset included a total of 7819 monthly test-day records of 1205 buffaloes located in 6 different farms and recorded by Cattle Information System/Egypt (CISE). The buffaloes having less than 5 test-day records were removed from the dataset. The test-day records after 300 days of lactation were excluded from the analysis. Also, the extreme and abnormal phenotypic values of daily milk yield, milk fat and milk protein percentage were removed from the dataset to avoid errors in sampling and / or in analysis. Finally, the edited dataset used for analyses included 5344 test-day records of 813 buffalo from 5 different commercial farms located in 5 different governorates of Egypt plus the experimental farm of the Faculty of Agriculture, Cairo University, Giza, Egypt. For each cow, test-day milk, fat, protein and lactose yields in milk were analyzed in the CISE Lab.

\section{Statistical models:}

Three different models were tested for fitting the lactation curve of the Egyptian buffalo Wood (1967), Wilmink (1987) and Guo and Swalve, (GSM), (1995) as the following:

$$
\text { Wood: } Y_{t}=a^{b} \mathbf{e}^{-c t}
$$

Where, $Y_{t}$ is the yield in day $t$ of lactation. According to Wood (1967), uses the method of least squares to obtain estimates for three parameters in the incomplete gamma function: $a$ is a scaling factor associated with the average yield, $b$ is related to pre-peak curvature and $\mathrm{c}$ is related to post-peak curvature.

Wilmink: $\mathrm{Y}_{\mathrm{t}}=\mathbf{a}+\mathbf{b} \mathrm{e}^{-\mathrm{kt}}+\mathbf{c t}$

Where, $Y_{t}$ is the yield in day $t$ of lactation. According to Wilmink (1987), the parameters $\mathrm{a}, \mathrm{b}$, and $\mathrm{c}$ are associated with the level of production, the increase of production before the peak, and with the subsequent decrease, respectively. Parameter $\mathrm{k}$ is related to the time of peak lactation and usually assumes a fixed value, derived from a preliminary analysis made on average production. This implies that the model has only 3 parameters to be estimated. In a preliminary analysis, $\mathrm{k}$ was estimated at 0.093 .

Guo and Swalve: $\mathrm{Yt}=\mathrm{a}+\mathrm{b} \sqrt{\mathrm{t}}+\mathrm{c} \ln (\mathrm{t})$

$\mathrm{Y}_{\mathrm{t}}$ is the yield in day $\mathrm{t}$ of lactation. Guo and Swalve model is an empirical three coefficient model that is considered worthy of investigation, because they have been proven to have a better fit than other models that have biological interpretation. 
The main effects included in the analysis were farm, year-season of calving, milking time (morning or evening) and parity. The parities ranged from 1 to 10 parities, where the parities number higher than 10 were grouped together with the tenth parity because these parities had few numbers of observations.

\section{Model Comparison:}

Three criteria were used to compare the goodness of fit of these models. The first was the Mean Square Prediction Error (MSPE) value (Kvanli, et al., 1986) as follows:

$$
M S P E=\frac{\sum_{t=1}^{n} e_{t}^{2}}{n}
$$

Where $e_{t}$ is the residual for observation $t$ and $n$ is the number of predicted values obtained.

The second was Akaike Information Criterion (1974) AIC and the third was Schwartz's Bayesian Information Criteria (1978) BIC as follows:

$\mathrm{AIC}=-2 \log \mathcal{L}(\Phi \mid \mathrm{y})+2 \mathrm{k}$

$\mathrm{BIC}=-2 \log \mathcal{L}(\Phi \mid \mathrm{y})+\mathrm{k} \ln (\mathrm{n})$

Where $\mathcal{L}(\Phi \mid \mathrm{y})$ is the maximum likelihood for the model and $\mathrm{k}$ is the number of parameters in the model and $\mathrm{n}$ is the sample size. The AIC takes into account both the statistical goodness of fit and the number of parameters that have to be estimated to achieve this particular degree of fit, by imposing a penalty for increasing the number of parameters. Lower values of the AIC and BIC indicate the preferred model. However, AIC values may sometimes lead to model over fitting.

The statistical analysis was done by R program (2010) using "nlme" package (Pinherio et al., 2010).

\section{RESULTS AND DISCUSSION}

The estimated regression parameters of the studied traits using the three models are shown in Table 1. The values of scaling factor associated with the average yield (a), pre-peak curvature (b) and post-peak curvature (c) of each model and for different milk yield and milk contents traits were present in Table (1).

The expected daily milk yield at the beginning of lactation (the $6^{\text {th }}$ day of lactation) was $8.90,9.16$ and $8.26 \mathrm{~kg}$ in WM, GSM and WD, respectively, then increased to reach the peak 10.65 (the $29^{\text {th }}$ day of lactation), $10.67 \mathrm{~kg}$ (the $26^{\text {th }}$ day of lactation) and $9.08 \mathrm{~kg}$ (the $28^{\text {th }}$ day of lactation) in WM, GSM and WD, respectively (Table 2). The daily milk production decreased to $2.41,2.64$ and $3.55 \mathrm{~kg}$ in WM, GSM and WD, respectively, at the end of the lactation period. Figure 1 indicates that the high level of milk yield in the Egyptian buffalo lasts for very short-time which reflects the low persistency of the animal. Buffaloes were unique in reaching the peak milk yield faster with low persistency and a slight linear gradual reduction in milk production.

Table 1. The expected equations of the studied traits using the relevant three models 


\begin{tabular}{lccc}
\hline Trait & \multicolumn{4}{c}{ Expected equation } \\
\hline Milk yield & $11.89-4.91 \mathrm{~W}^{-0.093 \mathrm{t}}-0.031 \mathrm{t}$ & $\underline{\text { Guo and Swalve }}$ & $\underline{\underline{\text { Wood }}}$ \\
Fat yield & $0.69-0.43 \mathrm{e}^{-0.093 \mathrm{t}}-0.001 \mathrm{t}$ & $0.19-0.09 \sqrt{\mathrm{t}}+3.46 \ln (\mathrm{t})$ & $1.9 \mathrm{n}^{0.13} \mathrm{e}^{-0.005 \mathrm{n}}$ \\
Protein yield & $0.44-0.10 \mathrm{e}^{-0.093 \mathrm{t}}-0.001 \mathrm{t}$ & $0.30-0.05 \sqrt{t}+0.10 \ln (\mathrm{t})$ & $-1.03 \mathrm{n}^{0.13} \mathrm{e}^{-0.003 \mathrm{n}}$ \\
Lactose yield & $0.61-0.33 \mathrm{e}^{-0.093 \mathrm{t}}-0.002 \mathrm{t}$ & $0.26-0.08 \sqrt{t}+0.21 \ln (\mathrm{t})$ & $-1.27 \mathrm{n}^{0.07} \mathrm{e}^{-0.004 \mathrm{n}}$ \\
Fat \% & $4.85+0.45 \mathrm{e}^{-0.093 \mathrm{t}}+0.010 \mathrm{t}$ & $5.66+0.37 \sqrt{t}-0.75 \ln (\mathrm{t})$ & $1.66 \mathrm{n}^{0.00} \mathrm{e}^{-0.001 \mathrm{n}}$ \\
Protein \% & $3.42+1.03 \mathrm{e}^{-0.093 \mathrm{t}}+0.002 \mathrm{t}$ & $4.47+0.12 \sqrt{t}-0.47 \ln (\mathrm{t})$ & $1.42 \mathrm{n}^{-0.05} \mathrm{e}^{-0.001 \mathrm{n}}$ \\
Lactose \% & $5.27-0.91 \mathrm{e}^{-0.093 \mathrm{t}}-0.002 \mathrm{t}$ & $4.36-0.11 \sqrt{t}+0.41 \ln (\mathrm{t})$ & $1.52 \mathrm{n}^{0.04} \mathrm{e}^{-0.001 \mathrm{n}}$ \\
\hline
\end{tabular}

Table 2. Daily milk yield and its contents traits at the $6^{\text {th }}$ day of lactation and minimum and peak production of Egyptian buffalo

\begin{tabular}{|c|c|c|c|c|c|c|}
\hline \multirow[t]{2}{*}{ Model } & \multirow[t]{2}{*}{ Trait } & \multirow{2}{*}{$\begin{array}{c}\text { The } 6^{\text {th }} \\
\text { day of } \\
\text { lactation }\end{array}$} & \multicolumn{2}{|c|}{$\begin{array}{c}\text { Minimum } \\
\text { production }\end{array}$} & \multicolumn{2}{|c|}{ Peak production } \\
\hline & & & Value & $\begin{array}{c}\text { Days in } \\
\text { milk (day) }\end{array}$ & Value & $\begin{array}{c}\text { Days in } \\
\text { milk (day) }\end{array}$ \\
\hline \multirow{6}{*}{ Wilmink } & Milk Yield (kg) & 8.90 & 2.41 & 300 & 10.65 & 29 \\
\hline & Fat Yield (kg) & 0.43 & 0.18 & 300 & 0.62 & 34 \\
\hline & $\begin{array}{c}\text { Protein Yield } \\
(\mathrm{kg})\end{array}$ & 0.37 & 0.09 & 300 & 0.40 & 22 \\
\hline & $\begin{array}{l}\text { Lactose Yield } \\
(\mathrm{kg})\end{array}$ & 0.42 & 0.11 & 300 & 0.55 & 31 \\
\hline & Fat $(\%)$ & 5.17 & 5.11 & 15 & 7.93 & 300 \\
\hline & Protein $(\%)$ & 4.02 & 3.51 & 43 & 4.02 & 6 \\
\hline \multirow{8}{*}{ Guo\&Swalve } & Lactose $(\%)$ & 4.74 & 4.74 & 6 & 5.18 & 42 \\
\hline & Milk Yield (kg) & 9.16 & 2.64 & 300 & 10.67 & 26 \\
\hline & Fat Yield (kg) & 0.45 & 0.18 & 300 & 0.61 & 36 \\
\hline & $\begin{array}{l}\text { Protein Yield } \\
(\mathrm{kg})\end{array}$ & 0.37 & 0.09 & 300 & 0.41 & 20 \\
\hline & $\begin{array}{c}\text { Lactose Yield } \\
(\mathrm{kg})\end{array}$ & 0.44 & 0.12 & 300 & 0.54 & 30 \\
\hline & Fat $(\%)$ & 5.22 & 5.06 & 16 & 7.79 & 300 \\
\hline & Protein $(\%)$ & 3.94 & 3.53 & 56 & 3.97 & 300 \\
\hline & Lactose (\%) & 4.82 & 4.74 & 300 & 5.17 & 52 \\
\hline \multirow{7}{*}{ Wood } & Milk Yield (kg) & 8.26 & 3.55 & 300 & 9.08 & 28 \\
\hline & Fat Yield (kg) & 0.44 & 0.27 & 300 & 0.50 & 38 \\
\hline & $\begin{array}{l}\text { Protein Yield } \\
\quad(\mathrm{kg})\end{array}$ & 0.31 & 0.14 & 300 & 0.32 & 20 \\
\hline & $\begin{array}{l}\text { Lactose Yield } \\
(\mathrm{kg})\end{array}$ & 0.41 & 0.17 & 300 & 0.46 & 31 \\
\hline & Fat $(\%)$ & 5.32 & 5.32 & 6 & 7.61 & 300 \\
\hline & Protein $(\%)$ & 3.79 & 3.51 & 63 & 3.94 & 300 \\
\hline & Lactose (\%) & 4.89 & 4.67 & 300 & 5.14 & 57 \\
\hline
\end{tabular}




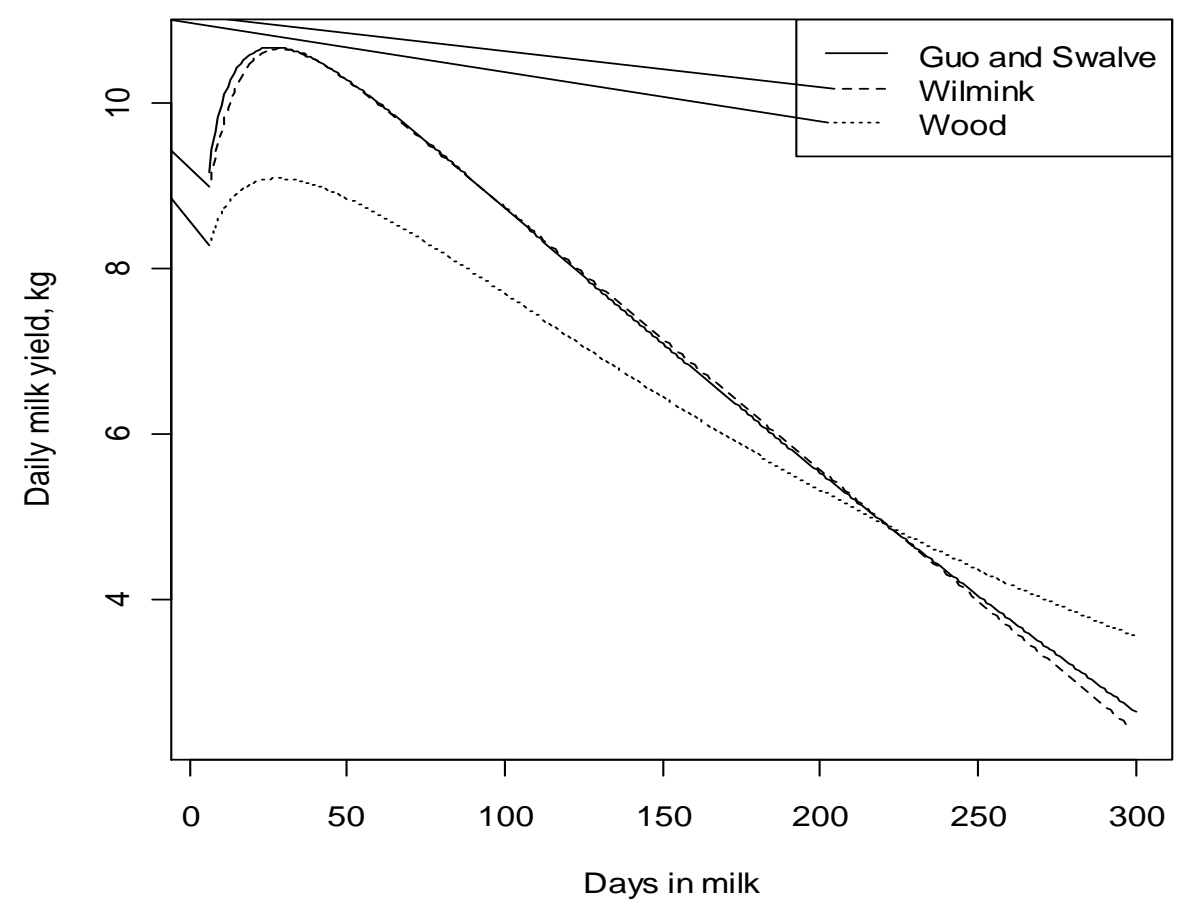

Figure 1. The estimated lactation curve of daily milk yield of the Egyptian buffalo

The present results are comparable to those cited by Sadek et al. (1998) which reported that the overall average peak milk yield was $58 \mathrm{~kg} /$ week using Wood function. First lactation had lower peak milk yield as compared with other lactations. The overall average of peak week, using 2158 lactation records, was 6.3 weeks (44 days). The first lactation peak week occurred earlier as compared with the subsequent lactations, indicating that the time required to each maximum weekly milk yield increased with parity.

In contrast, Barbosa et al. (2007) found that the incomplete gamma function must have a lactation peak. The lack of a lactation peak is likely due to the low level of nutrition of buffalo. Despite the high determination coefficient, the incomplete gamma function overestimated the lactation curve of buffaloes, creating an asymptote after the curve inflection.

Aziz et al. (2006) stated that in the first parity, the incomplete gamma function slightly underestimated milk yield in the periods between the second and fifth weeks and between week 17 and 34, then it overestimated actual milk yield up to week 48, and finally underestimated it up to the end of lactation. Wood model perfectly predicted the actual milk yield of the fifth parity, but slightly underestimated peak yield. In parity 10, the lactation curves estimated by Wood functions were more or less flat. It gave higher initial production (over-prediction) and flatter peaks (under- 
prediction). This could be due to shifting the model further on the hyperbolic tangent curve because milk yield declines linearly after approximately 7 weeks in milk.

Several workers have estimated lactation curve parameters of Egyptian buffaloes. Samak et al. (1988) described lactation curve of milk yield of Egyptian buffaloes using the linear form of the incomplete gamma function and reported values of the initial milk yield (a) ranging between 17.43 and $27.43 \mathrm{~kg}$ in the first and fourth parities, respectively. The rate of increase to peak production (b) and the rate of decline after peak (c) in their study ranged between 0.421 and $0.537 \mathrm{~kg}$ and between 0.04 and $0.05 \mathrm{~kg}$, respectively and they were higher than the corresponding values found in the present study. Aziz et al. (2003) found that the values of the initial milk yield (a) for the first six lactations are ranging between 30.30 and $44.38 \mathrm{~kg}$. The rate of increase to peak production (b) in their study ranged between 0.17 and $0.27 \mathrm{~kg}$ and those of the rate of decrease after peak (c) were between 0.02 and $0.03 \mathrm{~kg}$.

Olori et al. (1999) reported that predicted week of peak yield and yield at peak for Holstein-Friesian herd was 9 week and $31.4 \mathrm{~kg}$ milk, respectively, for using Guo and Swalve model while was 7 week and $32.0 \mathrm{~kg}$ milk for using Wilmink model. Lactation curve show that first lactation cows produce lower yields than older cows at the beginning of the lactation and were, as expected, more persistent (Tekerli et al., 2000 and Chaudhry et al. 2000). Multiparous cows on the other hand reach their peak of production earlier in the lactation (5-6th week of lactation) than first parity cows (7-10th week of lactation). Rekik et al. (2003) reported that the peak yield was greater for older (23-34 kg) than for primiparous cows (17-29 kg). Chaudhry et al. (2000) found that peak milk yield averaged $10.8 \mathrm{~kg}$ with average days to peak of 48 days in Nile Ravi buffalo. 


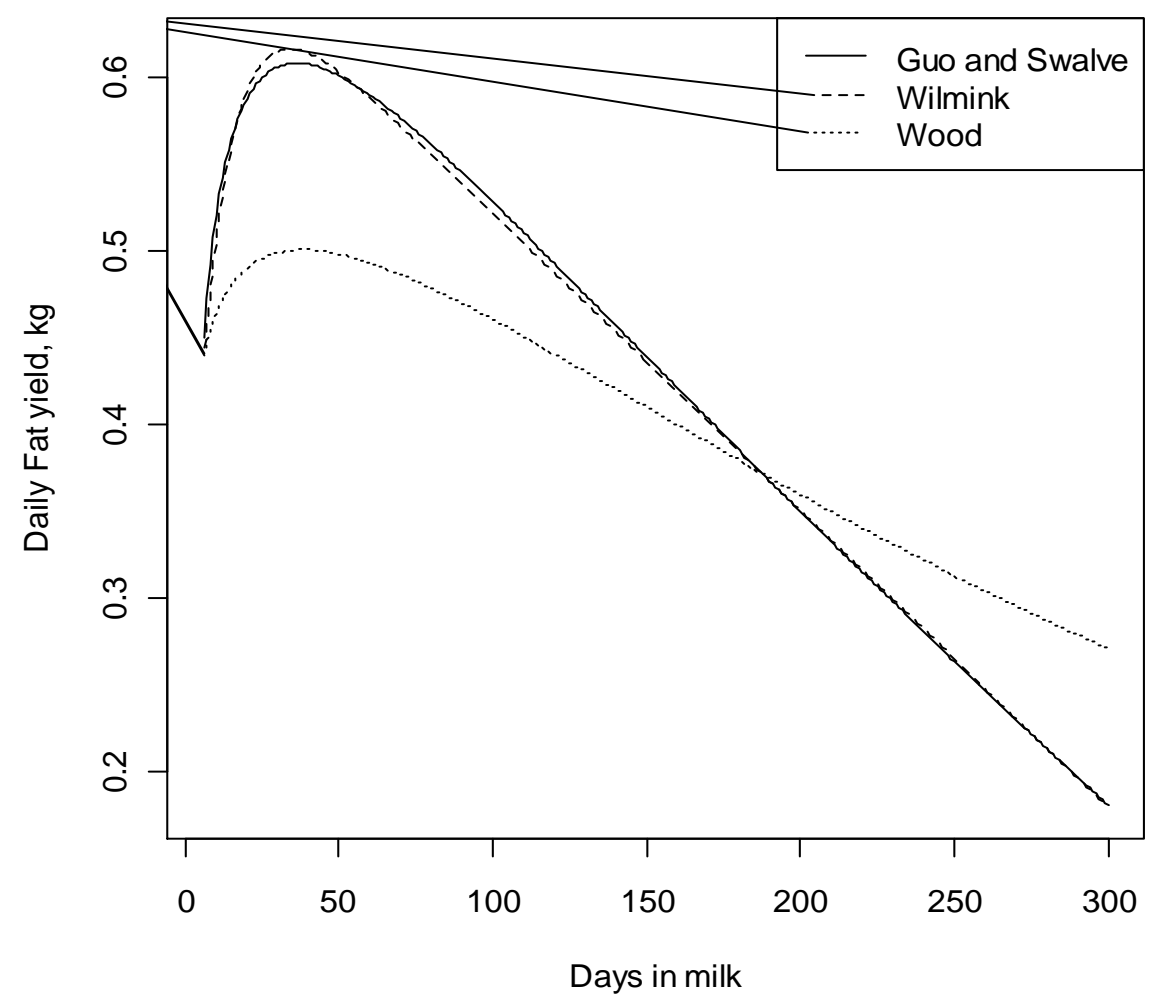

Figure 2. The estimated curves of milk fat yield (Kg) of the Egyptian buffalo

The curves of milk fat, milk protein and lactose yields had similar pattern to that of the daily milk yield. The expected daily fat yield (Figure 2) at the beginning of lactation (the $6^{\text {th }}$ day of lactation) was $0.43,0.45$ and $0.44 \mathrm{~kg}$ in WM, GSM and WD, respectively, and then increased to reach the peak of 0.62 (the $34^{\text {th }}$ day of lactation) and $0.61 \mathrm{~kg}$ (the $36^{\text {th }}$ day of lactation) in both WM and GSM, respectively, and 0.50 $\mathrm{kg}$ (the $38^{\text {th }}$ day of lactation) in WD model. The daily fat production decreased to $0.18 \mathrm{~kg}$ in both WM and GSM and $0.27 \mathrm{~kg}$ in WD at the end of the lactation period.

The expected daily milk protein yield (Figure 3) at the beginning of lactation (the $6^{\text {th }}$ day of lactation) was $0.37 \mathrm{~kg}$ in WM and GSM and 0.31 in WD, then increased to reach the peak $0.40 \mathrm{~kg}$ (the $20^{\text {th }}$ and $22^{\text {th }}$ days of lactation) in WM and GSM and 0.32 $\mathrm{kg}$ (the $20^{\text {th }}$ day of lactation) in WD. Thereafter the daily protein yield decreased to $0.09 \mathrm{~kg}$ in $\mathrm{WM}$ and GSM and to $0.14 \mathrm{~kg}$ in WD at the end of the lactation period (300 days).

The expected daily lactose yield (Figure 4) at the beginning of lactation (the $6^{\text {th }}$ day of lactation) was $0.42,0.44$ and $0.41 \mathrm{~kg}$ in WM, GSM and WD, respectively, then increased to reach the peak 0.46 and $0.55 \mathrm{~kg}$ (the $31^{\text {th }}$ day of lactation) in WM and WD, respectively, and $0.54 \mathrm{~kg}$ (the $30^{\text {th }}$ day of lactation) in GSM. The daily lactose production decreased to $0.11 \mathrm{~kg}$ in WM and GSM and $0.17 \mathrm{~kg}$ in WD at the end of the lactation period. 


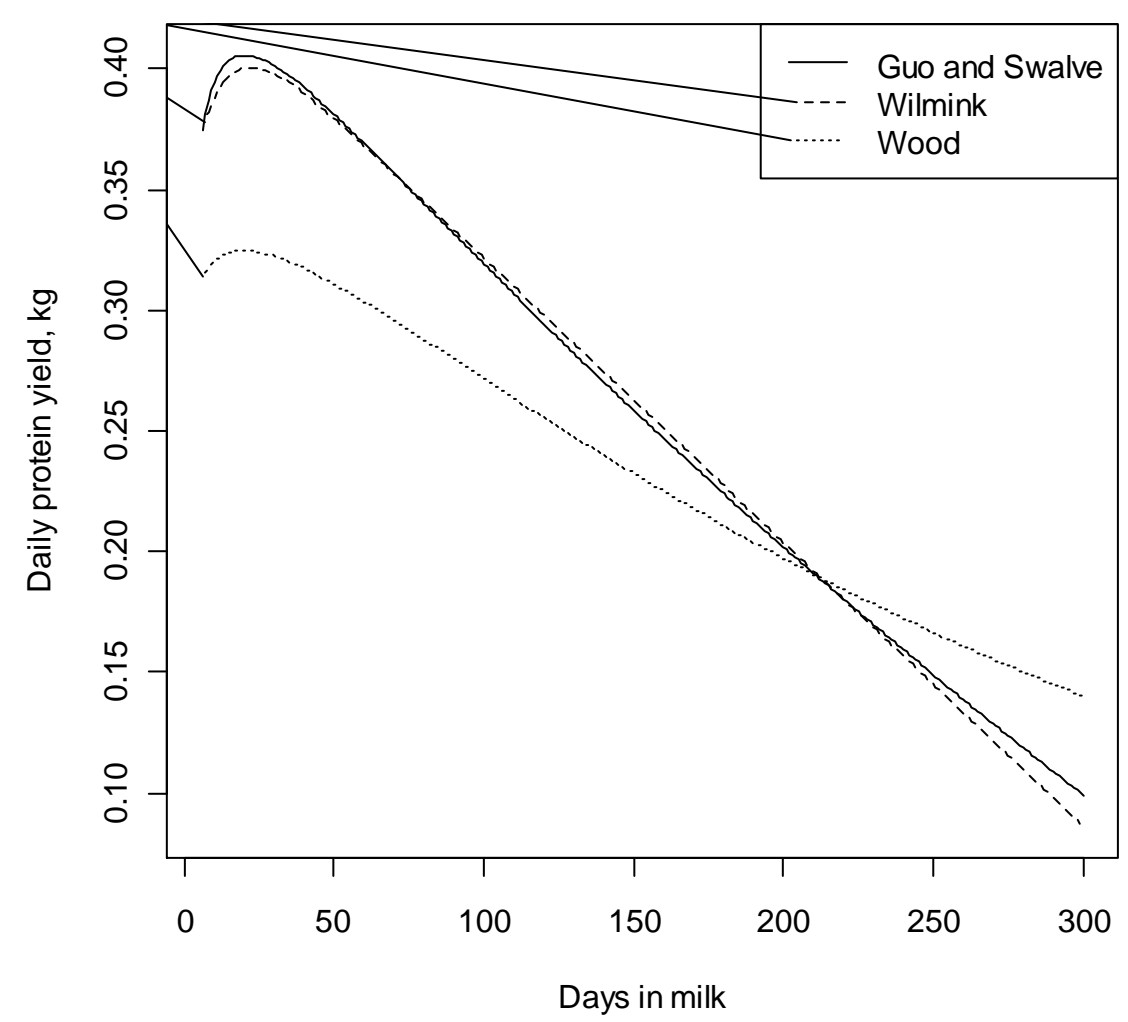

Figure 3. The estimated curves of milk protein yield $(\mathrm{Kg})$ of the Egyptian buffalo

The usual description of milk secretion refers to the occurrence of changes in milk contents during lactation, being the decrease of milk yield accompanied by the increase in fat and protein percentage. The shapes for daily milk yield and the reversed standard shape for milk components (Fat \%, Protein \%), were in agreement with previous works for dairy cattle (Pollott, 2004 and Silvestre et al., 2009). 


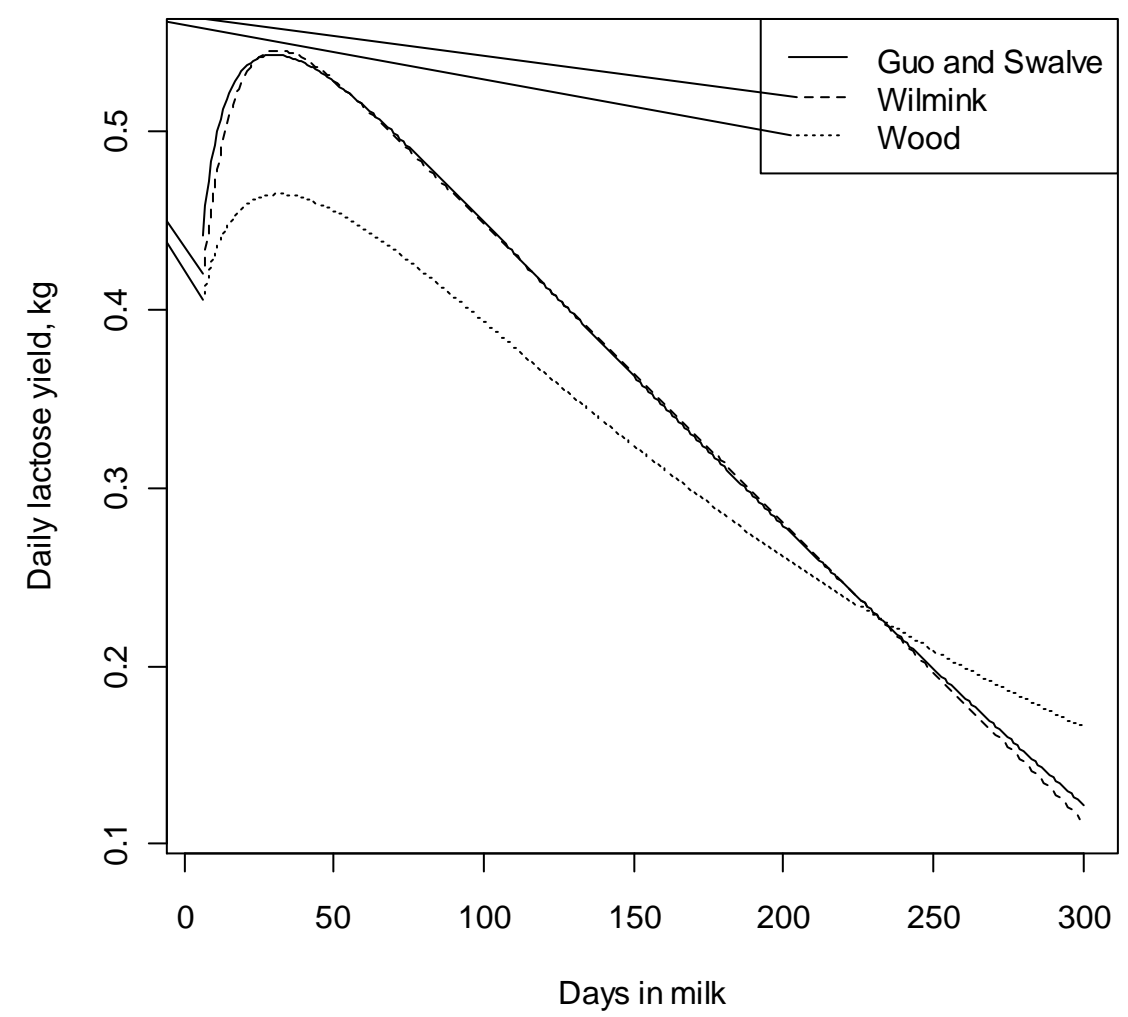

Figure 4. The estimated curves of milk lactose yield (kg) of the Egyptian buffalo

The milk fat percentage seems to have an increasing trend with the increase of lactation day. At the beginning of the lactation, the fat percentage in the three models was ranged from 5.17 to $5.32 \%$ then decreased very slightly to $5.11 \%$ at the $15^{\text {th }}$ day of lactation then increased to $7.93 \%$ at the end of lactation (Figure 5).

Also, the curve of milk protein percentage had increasing trend, but the change in the protein percentage along the lactation period was very low where at the beginning of the lactation, the protein percentage was 4.02, 3.94 and 3.79\% in WM, GSM and $\mathrm{WD}$, respectively, then decreased very slightly to $3.5 \%$ at the $43^{\text {rd }}, 56$ and 63 days of lactation in WM, GSM and WD, respectively, then increased to $4 \%$ at the end of lactation (Figure 6). 


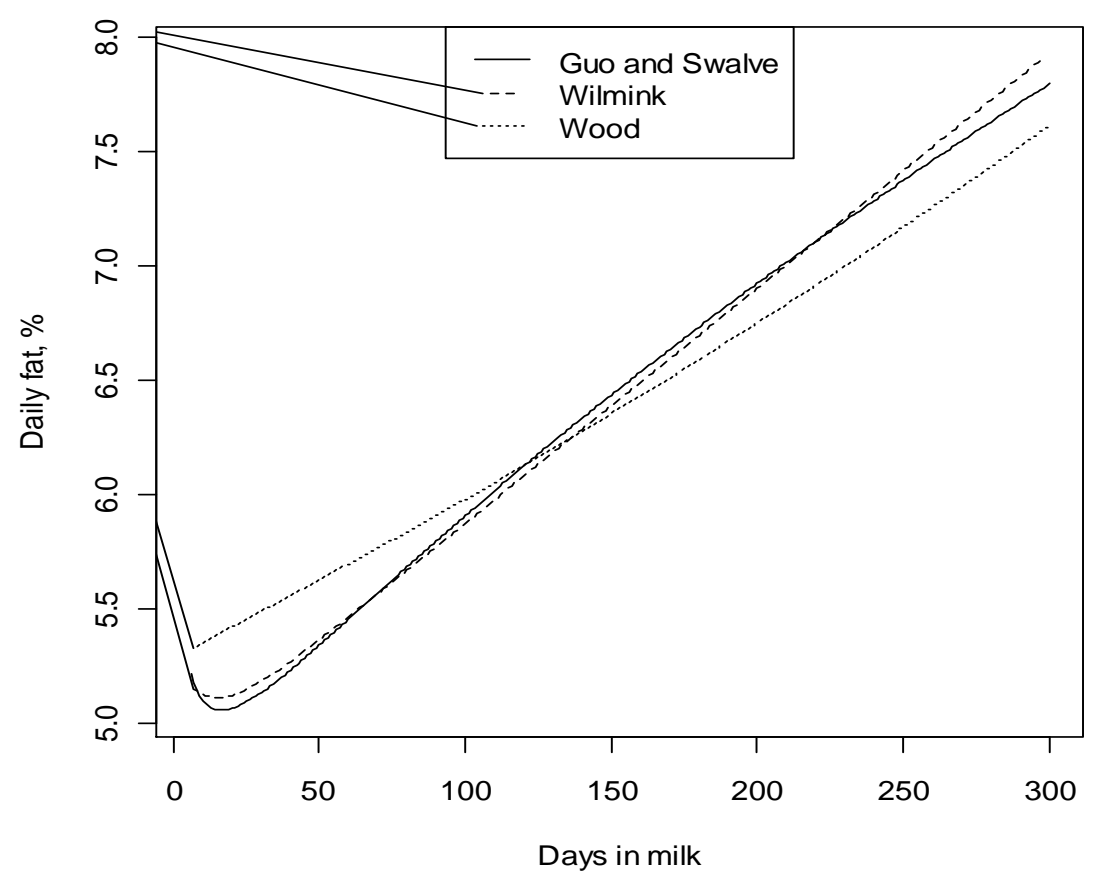

Figure 5: The estimated curve of milk fat percent of the Egyptian buffalo 


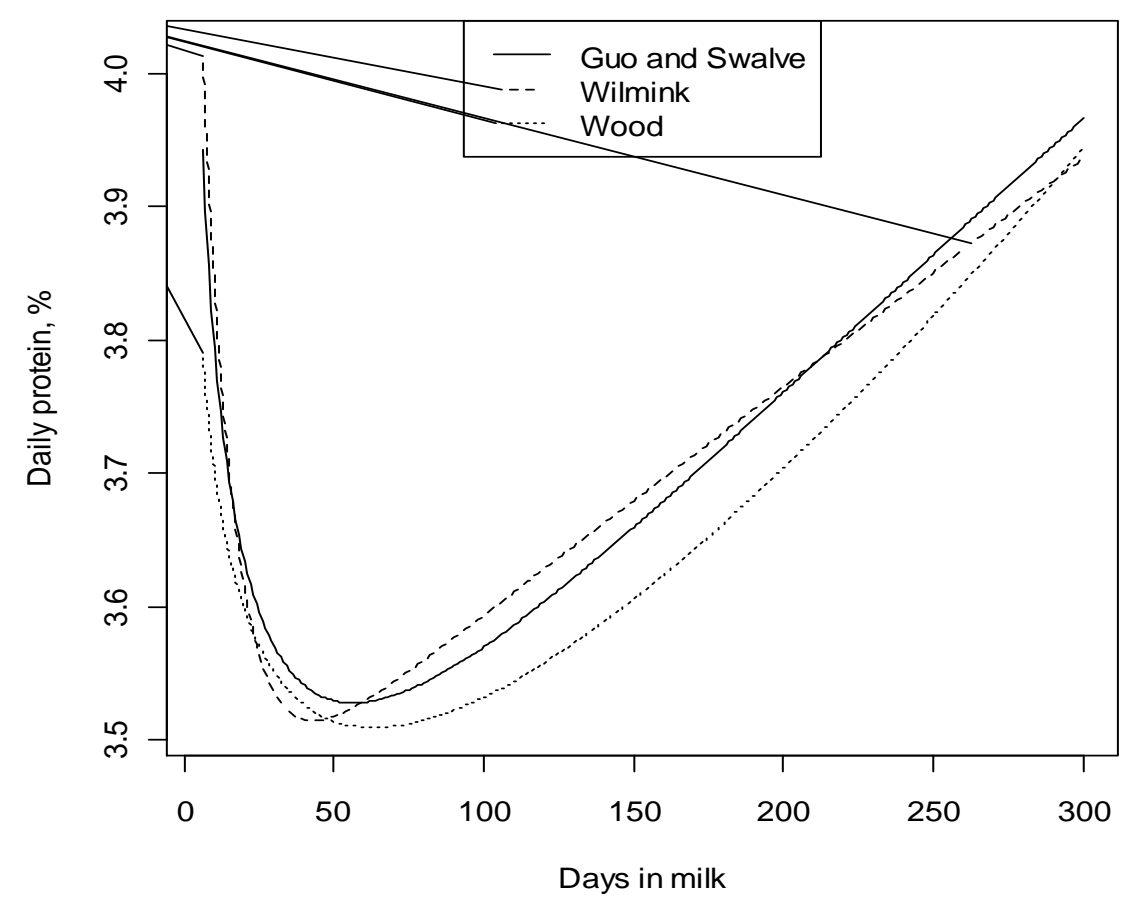

Figure 6. The estimated curve of milk protein percent of the Egyptian buffalo

The curve of milk lactose percentage was in contrast to the curves of the fat and protein percentages. Also, the change in the lactose percentage along the lactation period was very low where at the beginning of the lactation; the lactose percentage was $4.74 \%$ (WM) then increased very slightly to $5.18 \%$ at the $42^{\text {ed }}$ day of lactation then decreased to $4.7 \%$ at the end of lactation (Figure 7). 


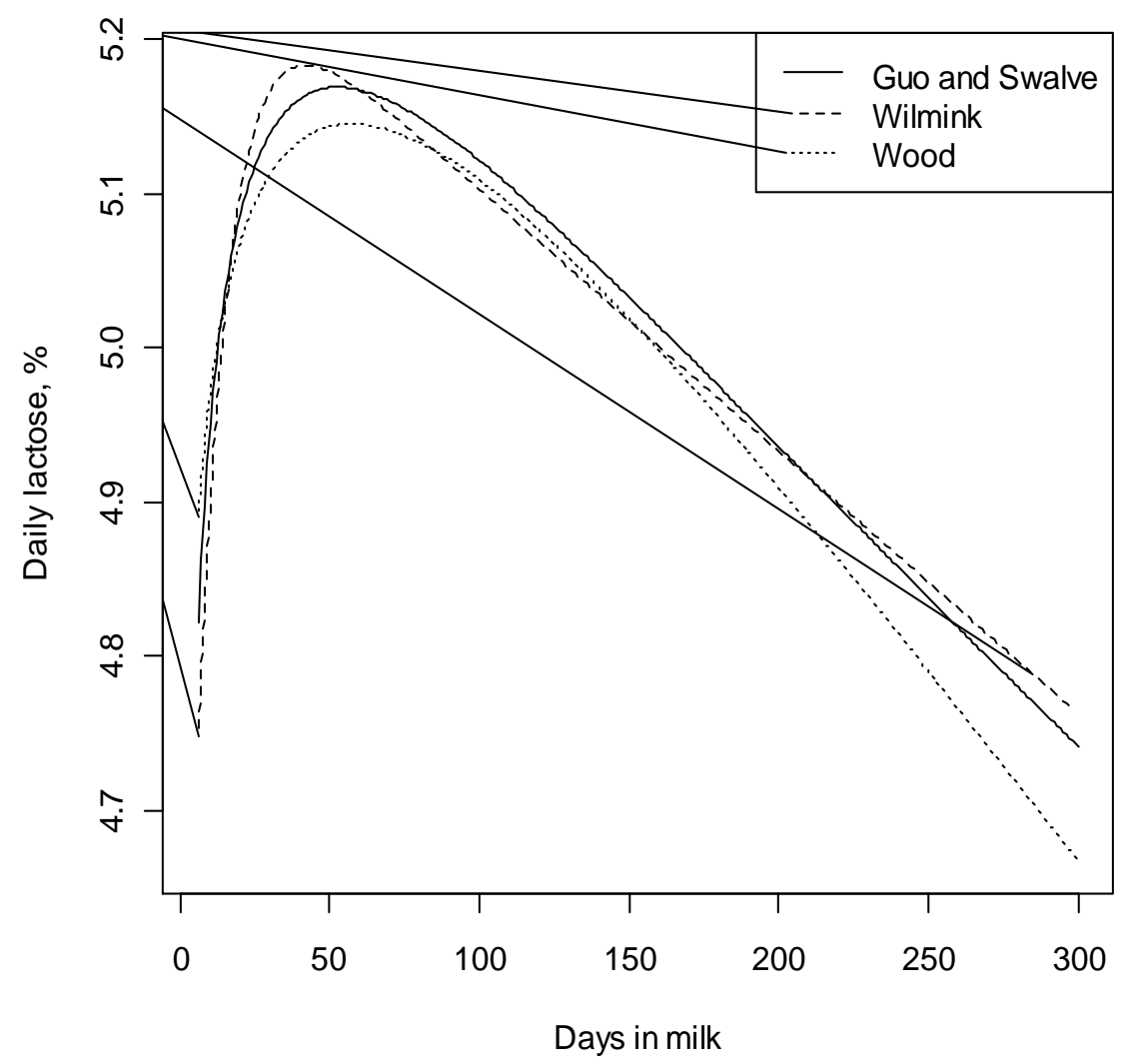

Figure 7. The estimated curve of milk lactose percent of the Egyptian buffalo

The Goodness of fit statistics of expected curves for daily milk yield and its contents using three different comparison criteria (MSPE, AIC and BIC) were present in Table 3.

The preliminary examination indicated that these models fitted to data richly. Table 3 showed that the estimated Akaike Information Criteria (AIC) for the Wood's model were lowers for all traits which mean that WD model provides better fitting for the curves of the all studied traits.

In conclusion, Wood (WD) model gave the best fit with a MSPE, BIC and AIC values. Guo and Swalve's model produced curves similar to the curves of Wilmink's model. 
Table 3. Goodness of fit statistics of expected curves of Egyptian buffalo for daily milk yield and its contents

\begin{tabular}{llccc}
\hline Model & Traits & MSPE & AIC & BIC \\
\hline & Milk Yield & 9.97 & 27551 & 27709 \\
Wilmink & Fat Yield & 0.08 & 2318 & 2475 \\
& Protein Yield & 0.02 & -5339 & -5182 \\
& Lactose Yield & 0.03 & -3887 & -3729 \\
& Fat \% & 2.69 & 20568 & 20726 \\
& Protein \% & 0.22 & 7289 & 7447 \\
& Lactose \% & 0.23 & 7500 & 7658 \\
\hline \multirow{4}{*}{ Guo\&Swalve } & Milk Yield & 9.95 & 27535 & 27692 \\
& Fat Yield & 0.09 & 2311 & 2469 \\
& Protein Yield & 0.02 & -5357 & -5199 \\
& Lactose Yield & 0.03 & -3898 & -3740 \\
& Fat \% & 2.68 & 20554 & 20712 \\
& Protein \% & 0.22 & 7286 & 7443 \\
& Lactose \% & 0.23 & 7501 & 7659 \\
\hline \multirow{6}{*}{ Wood } & Milk Yield & 10.09 & 27422 & 27580 \\
& Fat Yield & 0.09 & 2108 & 2266 \\
& Protein Yield & 0.02 & -5615 & -5457 \\
& Lactose Yield & 0.03 & -4138 & -3980 \\
& Fat \% & 2.71 & 20497 & 20655 \\
& Protein \% & 0.22 & 7207 & 7365 \\
& Lactose \% & 0.23 & 7410 & 7568 \\
\hline
\end{tabular}

\section{ACKNOWLEDGEMENT}

The authors would like to acknowledge the Science and Technology Fund of Egypt (STDF) for financing this work through the project No.218 titled "Microsatellite markers: as a tool for genetic improvement of milk yield and its contents in Egyptian Buffaloes". Also, thanks to Dr. M.A. Ibrahim, AssociateProfessor, Department of animal production, Cairo University for advising in data analysis part.

\section{REFERENCES}

Akaike, H., 1974. A new look at the statistical model identification. IEEE Trans. Automat. Contr. 19:716-723.

Anwar, M., J. Philip Cain, P. Rowlinson, M. Sajjad Khan, M. Abdullah and M. Ellahi Babar, 2009. Factors affecting the shape of the lactation curve in Nili-Ravi Buffaloes in Pakistan. Pakistan J. Zool. Suppl. 9: 201-207.

Aziz, M.A., N.A. Shalaby, O.M. El-Shafie, A.T. Mahdy and A. Nishida, 2006. Comparison between the shapes of lactation curve of Egyptian buffalo milk yield estimated by the incomplete gamma function and a new model. Livestock 
Research for Rural Development. Volume 18, Article \#59. Retrieved January 20, 2011, from http://www.lrrd.org/lrrd18/5/aziz18059.htm

Aziz, M.A., A.E. Mahdy, O.M. El-Shafie and N.A. Shalaby, 2003. A comparison of different models of the lactation curve in Egyptian buffaloes. Journal of Agricultural Science, Mansoura University 28(7): 5253-5268.

Barbosa, S.B.P., R.G.A. Pereira, K.R. Santoro, A.M.V. Batista, A.C. Ribeiro Neto, 2007. Lactation curve of cross-bred buffalo under two production systems in the Amazonian region of Brazil. Ital. J. Anim. Sci. vol. 6, (Suppl. 2), 1075-1078.

Chaudhry, H.Z., M.S. Khan, G. Mohiuddin and M.I. Mustafa, 2000. Peak milk yield and days to attain peak in Nili Ravi buffaloes. Int. J. Agric. Biol. 2(4): 356- 358

Cunha, D.N. F.V., J.C. Pereira, F.F. Silva, O.F. Campos, J.L. Braga, J.A. Martuscello, 2010. Selection of models of lactation curves to use in milk production simulation systems. R. Bras. Zootec. 39(4):891-902.

Guo, Z. and H.H. Swalve, 1995. Modeling of lactation curve as a sub-model in the evaluation of test day records. Paper presented at the INTERBULL open meeting, 7-8 September, 1995, Prague, Czech Republic.

Kirkpatrick, M., D. Lofsvold and M. Bulmer, 1990. Analysis of the inheritance, selection and evolution of growth trajectories. Genetics 124:979-993.

Kvanli, A.H., C.S. Guynes and R.J. Pavur, 1986. Introduction to Business Statistics. Fourth Edition. West Publishing Company.

Macciotta, N. P. P., D. Vicario, and A. Cappio-Borlino, 2005. Detection of different shapes of lactation curve for milk yield in dairy cattle by empirical mathematical models. J. Dairy Sci. 88:1178-1191.

Mepham, T.B., 1987. Physiology of lactation. Pp. 71- 91.Milk Biosynthesis. Open University press, Milton Keynes Philadelphia, USA.

Neal, H.D., and J.H.M. Thornley, 1983. The lactation curve in cattle: A mathematical model of the mammary gland. J. Agric. Sci. Camb. 101:389-400.

Olori, V.E., S. Brotherstone, W.G. Hill, B.J. McGuirk, 1999. Fit of standard models of the lactation curve to weekly records of milk production of cows in a single herd. Livestock Production Science 58:55-63.

Papajcsik, I.A., J. Bodero, 1988. Modeling lactation curves of Friesian cow in a subtropical climate. Animal Prod. 47(2):201-207.

Pinheiro, J., D. Bates, S.DebRoy, D.Sarkar and the R. Development Core Team, 2010. nlme: Linear and Nonlinear Mixed Effects Models. R package version 3.197.

Pollott, G.E., 2004. Deconstructing milk yield and composition during lactation using biologically based lactation models. J. Dairy Sci. 87,2375-2387.

Quinn, N., L. Killen and F. Buckley, 2005. Empirical algebraic modeling of lactation curves using Irish data. Irish Journal of Agricultural and Food Research 44(1):1 13.

R. Development Core Team, 2010. R: A language and environment for statistical computing. R Foundation for Statistical Computing, Vienna, Austria. ISBN 3900051-07-0, URL http://www.R-project.org/.

Rekik, B., A. Ben Gara, M. Ben Hamouda and H. Hammami, 2003. Fitting lactation curves of dairy cattle in different types of herds in Tunisia. Livestock Production Science 83:309-315. 
Sadek, R.R., Mahasin, M. Mahamed, M.A.M. Ibrahim and Hoda, M.A. Abdel-Lattef. 1998. Estimation of lactation curve parameters in Egyptian buffaloes. Egyptian J. Anim. Prod. 35(1):1-27.

Samak, M.A, G.A. Hassan, A. Hassan and N. Yassen, 1988. The lactation curve and performance of the Egyptian buffalo. Alexandria Science Exchange 9: 83-97.

Schwartz, G. 1978. Estimating the dimension of a model. Ann. Stat. 6:461-464.

Silvestre, A.M., A.M. Martins, V.A. Santos, M.M. Ginja, J.A. Colaço, 2009. Lactation curves for milk, fat and protein in dairy cows: A full approach. Livestock Science 122:308-313.

Tekerli, M., Z. Akinci, I. Dogan, A. Ackan, 2000. Factors affecting the shape of lactation curves of Holstein cows from the Balikesir province of Turkey. J. Dairy Sci. 83, 1381-1386.

Wilmink, J.N.M., 1987 Adjustment of test day milk, fat and protein yield for age, season and stage of lactation. Livestock Production Science 16:335-348.

Wood, P.D.P., 1967. Algebraic model of the lactation curve in cattle. Nature, London 216: 164-165. (Cited by Quinn et al., 2005). 


\section{ملائمة منحنى الحليب للجاموس المصرى بإستخدام ثلاثة نماذج}

سامح عبد الفتاح محمد عبد السلام'، وجدى مكاوى'، ياسين محمد حافظ'، أحمد عبد الصمد زكى'، سامى أبو بكر' سبد

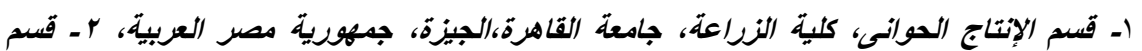
الإنتاج الحوانى، كلية النزاعة، جامعة عين شمس، القاهرة، جمهورية مصر العربية

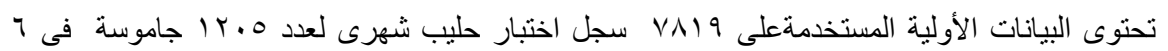

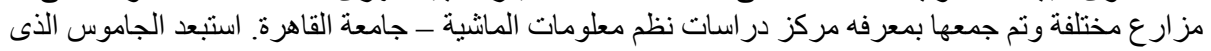

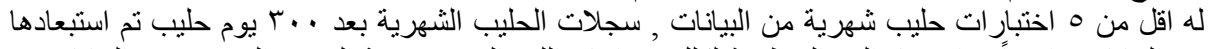

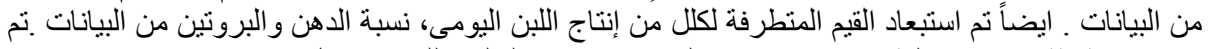

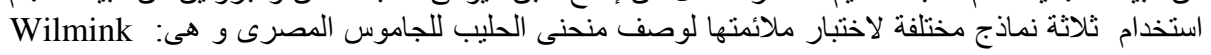
Guo and Swalve Wood

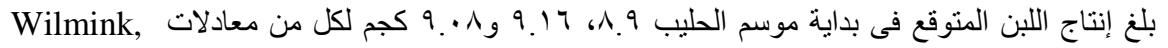
Guo and Swalve and Wood

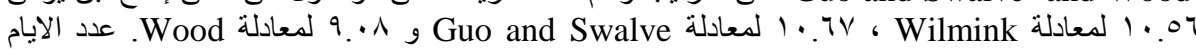

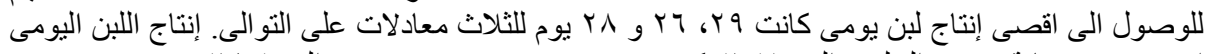

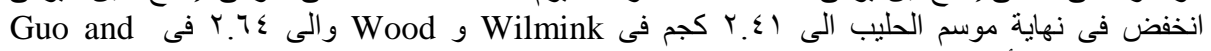
Swalve

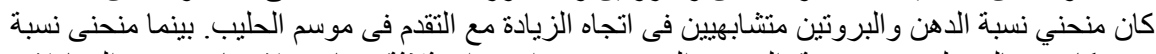

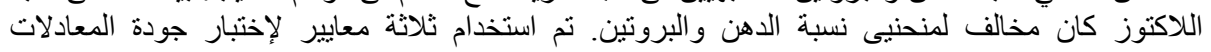

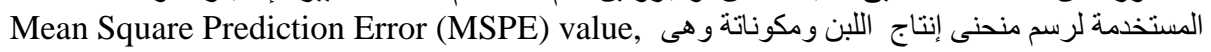
Akaike Information Criterion (AIC) and Schwartz's Bayesian Information Criteria مكوناتة هي معادلة Wood المستخمة في هذه الدراسة اوضحت ان افضل معادلة يمكن استخدامها لرسم منحنى اللبن 